\title{
Estimating The Economic Impact Of Local Cultural Organizations: The Charlotte Arts \& Science Council Example
}

John E. Connaughton, University of North Carolina at Charlotte Ronald A. Madsen, University of North Carolina at Charlotte Rob Roy McGregor, University of North Carolina at Charlotte

\begin{abstract}
This paper details the impact of the 58 affiliated members of the Charlotte Arts \& Science Council on the economy of Mecklenburg County, North Carolina. We find that the affiliated members of the Arts \& Science Council had a sizable impact on the Mecklenburg economy. Output was expanded by \$129,171,622; earnings were increased by \$50,589,999; and employment was increased by 2,132 full-time equivalent jobs. These economic impacts were an important addition to the rich and varied cultural offerings provided by the Arts \& Science Council affiliates.
\end{abstract}

\section{INTRODUCTION}

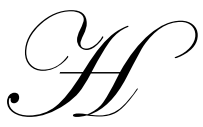

istorically, the arts have provided a rich and diverse cultural environment integral to the overall health and vitality of metropolitan areas. More recently, the arts have also been playing an increasingly important role in the economic prosperity of metropolitan areas. Charlotte, as an emerging national metropolitan region, is no different. The city's cultural community is now recognized as a key component of the region's economic development infrastructure. This role requires the cultural community to grow with the region, and this growth requires more resources. As resource demands increase, so does accountability. As a result, cultural communities have come under increased pressure to demonstrate their economic viability within the local community.

The structure of the Charlotte cultural community is somewhat unique. All of the major organizations (symphony, opera, dance, and museums) are members of one umbrella organization, the Charlotte Arts \& Science Council (ASC). The ASC is a non-profit organization that serves and supports Charlotte-Mecklenburg's cultural community through grant-making, planning, programs, and services designed to ensure a vibrant community that is enriched with arts, science, and history. The Council was organized in 1958 with a mission of combining resources from the Annual Fund Drive; allocations from local, state, and federal governments; and its endowment to support cultural organizations, educational programs, and individual artists throughout the region.

This paper reports estimates of the economic impact of the ASC and its 58 affiliated member organizations on output, employment, and earnings in the local economy. It is important to note that there are intrinsic social and cultural impacts of the organizations that are not reflected in the results. These intrinsic impacts significantly enhance the overall contribution of these arts, science, and history organizations to the quality of life in the Charlotte metropolitan area.

\section{LITERATURE REVIEW}

There have been a number of studies undertaken to estimate the economic impact of the arts and other cultural activities on local communities. For the most part, these studies suffer from three shortcomings. First, they tend to use a methodology that is not based on an input/output model. The multipliers that are used are nonindustry-specific and ad hoc. For example, Real Estate Research Consultants (2004) used a hypothetical multiplier 
of 2.0 in their study of the Orlando, FL, arts community. The North Carolina Arts Council (2004) used a hypothetical multiplier of 1.5 . Buehler and Trapp (2001) used a hypothetical multiplier of 2.5 in their study of Oregon's non-profit arts sector.

Second, spending estimates sometimes rely on consumer surveys or ad hoc estimates. For example, DeMaio (2004) used a wide range of secondary data sources such as Occupational and Employment Statistics, Quarterly Census of Employment and Wages, and state industry and occupation employment projections. The use of secondary data sources means that the study included the total employment within an industry or occupational group even if some of the employment was not engaged in the arts. Stronge (2004), Wessex Group (2000), and Real Estate Research Consultants (2004) all used grant applications as part of their data collection process for arts and cultural organizations. This practice can result in a less than complete data set.

Third, most studies do not address the substitution (re-spending) problem. For example, the North Carolina Arts Council (2004), Swenson and Eathington (2003), and Chiappe and Nelson (2003) all either do not mention the issue or assume it is not a problem. Alliance for the Arts (1997) and Robey and Kleinhenz (2000) recognized that local arts and cultural spending by local residences may block or reduce leakages but did not specifically attempt to measure the magnitude of this effect.

In the analysis reported in this paper, we have tried to address each of these three concerns. ${ }^{1}$ First, we use the widely-accepted IMPLAN methodology to estimate the multiplier effect (Minnesota IMPLAN Group 2001). IMPLAN allows us to assign the different components of the cultural community to specific industry categories. Second, the direct impact estimates are based on the annual operating budgets of the cultural organizations and on the results from surveys of attendees about off-site expenditures associated with their attendance at cultural events. Third, we use the results from surveys of local residents about their potential out-of-region spending on cultural activities to estimate the extent of leakage blocking. This allows us to adjust our economic impact estimates to account for the substitution problem.

\section{THE CHARLOTTE-MECKLENBURG ARTS \& SCIENCE COUNCIL}

The economic impacts measured in this study are for Mecklenburg County, North Carolina. Mecklenburg County, which contains the rapidly growing city of Charlotte, had a 2004 population of 768,574. The 58 organizations affiliated with the ASC (as of fiscal year 2003-2004) provide services and programs that directly serve area residents. For example, when large-scale productions like Miss Saigon or The Lion King are presented in Charlotte, a significant portion of attendees come from surrounding counties. When these patrons visit Charlotte, they have a positive impact on the local economy that extends beyond the price of their ticket. In addition, while organizations like the Charlotte Symphony, Discovery Place, the Mint Museums, and Opera Carolina primarily serve the local community, they also attract a substantial number of visitors from outside Mecklenburg County.

Money spent by visitors in Mecklenburg County at restaurants, entertainment establishments, hotels, motels, retail shopping stores, and gas and service stations provides a direct benefit to the local economy. These "off-site" impacts are added to the economic impacts that occur "on-site" at the arts, science, and history organizations. The methodology used in this report includes both the "on-site" and "off-site" economic impacts of the affiliated members of the ASC on output, employment, and earnings.

The ASC and its affiliate organizations were surveyed during the fall of 2004, and the activity levels and economic impacts reported in this paper are based on these survey results. Of the 58 organizations, 36 provided information on their 2003-2004 activities. Of the 22 organizations that did not respond, nine provided data for an earlier study (Connaughton and McGregor 2001), so we used their previous data as estimates for the 2003-2004 season. Thirteen affiliates provided no data and were therefore excluded from the economic impact analysis.

\footnotetext{
${ }^{1}$ Gazel and Schwer (1997) also address each of these three issues. Their analysis focuses on the impact of three 1995 Grateful Dead concerts on the Las Vegas economy. By contrast, we examine the economic impact of ongoing local cultural organizations.
} 
We classified the ASC and each of its affiliates into two broad categories: (1) theatrical and performanceoriented organizations (Performance Organizations) and (2) museums, exhibitors, and other not-for-profit organizations (Museums and Other Organizations). These organizations provided more than 63,700 events and activities in fiscal year 2003-2004 (Table 1), thereby offering a range of choices to area residents and visitors that resulted in total attendance of over 2,600,000 (Table 2). Survey results indicated that Mecklenburg County residents attended an average of about four events during the year, while visitors to the county made up over 716,000 of the total attendance number.

Table 1

Arts \& Science Council Affiliate Organizations Summary of Activities and Events: 2003-2004

\begin{tabular}{lcccc}
\hline \multicolumn{1}{c}{ Activity } & Performance Organizations & Museums \& Others & Total & Percent of Total \\
\hline Performances & 1,564 & 27,920 & 29,484 & $46.28 \%$ \\
Exhibitions & 655 & 276 & 931 & $1.46 \%$ \\
Workshops & 19,847 & 4,239 & 24,086 & $37.81 \%$ \\
Tours & 252 & 4,548 & 4,800 & $7.53 \%$ \\
Other & 2,864 & 1,538 & 4,402 & $6.91 \%$ \\
\hline Total & 25,182 & 38,521 & 63,703 & $100.00 \%$ \\
\hline
\end{tabular}

Table 2

Arts \& Science Council Affiliate Organizations Summary of Attendance at Activities and Events: 2003-2004

\begin{tabular}{lcccccc}
\hline & \multicolumn{2}{c}{ Performance Organizations } & \multicolumn{2}{c}{ Museums \& Others } & \multicolumn{2}{c}{ Total } \\
\hline & Number & Percent & Number & Percent & Number & Percent \\
\hline Total Attendance & $1,438,358$ & $100.00 \%$ & $1,200,213$ & $100.00 \%$ & $2,638,571$ & $100.00 \%$ \\
\hline Out-of-County & 246,967 & $17.17 \%$ & 469,787 & $39.14 \%$ & 716,755 & $27.16 \%$ \\
\hline
\end{tabular}

For fiscal year 2003-2004, the ASC affiliate organizations had 512 full-time employees and 853 part-time employees who were paid a total of $\$ 27,954,179$ in compensation (Table 3). In addition, there were 5,974 volunteers who worked an average of 5.39 hours per week in 2003-2004. This level of service represents a total of $1,609,993$ hours of volunteered time (based on a 50-week work year). This volunteered labor time is the equivalent of 805 full-time employees working for these organizations. The value of the output of these volunteers was not measured in this study, but the quality and quantity of the services they provided was very significant. These volunteers enhanced the quality of life for all those who attended or participated in the events and activities provided by the ASC affiliate organizations.

Table 3

Arts \& Science Council Affiliate Organizations Summary of Employment and Payroll: 2003-2004

\begin{tabular}{cccc}
\hline Job Type & Number of Jobs & Average Hours/ Week & Annual Payroll \\
\hline Full-time & 512 & N/A & $\$ 18,543,486$ \\
Part-time & 853 & 15.76 & $\$ 9,410,693$ \\
Volunteer & 5,974 & 5.39 & N/A \\
\hline Total & 7,339 & N/A & $\$ 27,954,179$ \\
\hline
\end{tabular}

The economic health, diversity, and vitality of Mecklenburg County and the surrounding area clearly benefit from the wide range of programs and activities provided by the organizations that are affiliated with the ASC. The next section of this report explains how the economic impact of these organizations was measured. 


\section{ECONOMIC IMPACT METHODOLOGY}

The most important measures of the economic impact of an industry are output, jobs, and earnings. To assess accurately the total economic impact, the first piece of information that must be estimated is direct outputthe dollar output or employment associated with the firm or industry being evaluated. For this impact study, this is measured by the total expenditures of the ASC and each affiliated organization. In addition, some off-site expenditures by performers and attendees are also classified as direct.

The multiplier concept then captures the total effect of these organizations' direct output, employment, or earnings on the overall economy. For this analysis, output, employment, and earnings multipliers for the 2003-2004 operations of Performance Organizations and Museums and Other Organizations were obtained from the IMPLAN multiplier matrices for Mecklenburg County, North Carolina. These multipliers can be applied to direct output, employment, and earnings information to estimate the total impact of an industry on a region's economy. In addition, IMPLAN provides a comprehensive set of disaggregated multipliers that can be used to estimate the indirect impacts and the induced impacts separately from the total impact at the regional level. ${ }^{2}$

The IMPLAN multipliers used in our analysis are based on 2001 data and were the most recent available at the time of the impact study. Output multipliers are presented in Table 4; employment multipliers, in Table 5; and earnings multipliers, in Table 6 . The employment multipliers used in this study are expressed as jobs per $\$ 1$ million of output. The 2001 IMPLAN employment multipliers were therefore adjusted to reflection inflation that took place between 2001 and 2004.

\section{MECKLENBURG COUNTY ECONOMIC IMPACTS}

In this section, we present the output, employment, and earnings impacts of the ASC and its member organizations on the Mecklenburg County economy. Tables 7, 8, and 9 present the on-site, off-site, and total output impacts measured in dollars. Tables 10, 11, and 12 report the on-site, off-site, and total employment impacts measured in full-time equivalent jobs. Tables 13, 14, and 15 present the on-site, off-site, and total earnings impacts measured in dollars. Information in these tables was separated to reflect the output, employment, and earnings impacts of Performance Organizations and Museums and Other Organizations.

Table 4

2004 Output Multipliers

\begin{tabular}{lccccc}
\hline \multicolumn{1}{c}{ Category } & NAICS Code & $\begin{array}{c}\text { Direct } \\
\text { Multiplier }\end{array}$ & $\begin{array}{c}\text { Indirect } \\
\text { Multiplier }\end{array}$ & $\begin{array}{c}\text { Induced } \\
\text { Multiplier }\end{array}$ & $\begin{array}{c}\text { Total } \\
\text { Multiplier }\end{array}$ \\
\hline $\begin{array}{l}\text { On-site Output Multipliers } \\
\text { Performing arts companies }\end{array}$ & $7111 / 7113 / 7114 / 7115$ & 1 & & & \\
Museums, historical sites, zoos & 712 & 1 & 0.253136 & 0.273283 & 1.526419 \\
Off-site Output Multipliers & & & & & \\
Food services and drinking places & 722 & 1 & 0.289868 & 0.255452 & 1.545320 \\
Gasoline stations & 447 & 1 & 0.312886 & 0.265306 & 1.578192 \\
Miscellaneous store retailers & 453 & 1 & 0.368937 & 0.249979 & 1.618915 \\
Hotels and motels, including casinos & $72111 / 72112$ & 1 & 0.198760 & 0.238535 & 1.437295 \\
\hline
\end{tabular}

\footnotetext{
${ }^{2}$ The indirect effect is the additional economic activity of the regional supplier chain that is caused by the economic activity of the direct industry. The induced effect is the additional economic activity of all other unrelated firms and households in the region that is caused by the economic activity of the direct industry and its supplier chain.
} 
Table 5

2004 Adjusted Employment Multipliers

\begin{tabular}{|c|c|c|c|c|c|}
\hline Category & NAICS Code & $\begin{array}{c}\text { Direct } \\
\text { Multiplier }\end{array}$ & $\begin{array}{c}\text { Indirect } \\
\text { Multiplier }\end{array}$ & $\begin{array}{c}\text { Induced } \\
\text { Multiplier }\end{array}$ & $\begin{array}{c}\text { Total } \\
\text { Multiplier }\end{array}$ \\
\hline \multicolumn{6}{|l|}{ On-site Employment Multipliers } \\
\hline Performing arts companies & $7111 / 7113 / 7114 / 7115$ & 1 & 0.223393 & 0.156445 & 1.379838 \\
\hline Museums, historical sites, zoos & 712 & 1 & 0.510158 & 0.320930 & 1.831088 \\
\hline \multicolumn{6}{|l|}{ Off-site Employment Multipliers } \\
\hline Food services and drinking places & 722 & 1 & 0.094844 & 0.104987 & 1.199831 \\
\hline Gasoline stations & 447 & 1 & 0.166615 & 0.159940 & 1.326555 \\
\hline Miscellaneous store retailers & 453 & 1 & 0.170736 & 0.130961 & 1.301697 \\
\hline Hotels and motels, including casinos & $72111 / 72112$ & 1 & 0.080743 & 0.116701 & 1.197444 \\
\hline
\end{tabular}

Table 6

2004 Earnings Multipliers

\begin{tabular}{|c|c|c|c|c|c|}
\hline Category & NAICS Code & $\begin{array}{c}\text { Direct } \\
\text { Multiplier }\end{array}$ & $\begin{array}{c}\text { Indirect } \\
\text { Multiplier }\end{array}$ & $\begin{array}{c}\text { Induced } \\
\text { Multiplier }\end{array}$ & $\begin{array}{c}\text { Total } \\
\text { Multiplier }\end{array}$ \\
\hline \multicolumn{6}{|l|}{ On-site Earnings Multipliers } \\
\hline Performing arts companies & $7111 / 7113 / 7114 / 7115$ & 0.395910 & 0.080111 & 0.083610 & 0.559630 \\
\hline Museums, historical sites, zoos & 712 & 0.524572 & 0.161464 & 0.098073 & 0.784109 \\
\hline \multicolumn{6}{|l|}{ Off-site Earnings Multipliers } \\
\hline Food services and drinking places & 722 & 0.342888 & 0.081633 & 0.078154 & 0.502674 \\
\hline Gasoline stations & 447 & 0.336007 & 0.107355 & 0.081168 & 0.524530 \\
\hline Miscellaneous store retailers & 453 & 0.359135 & 0.126586 & 0.076482 & 0.562203 \\
\hline Hotels and motels, including casinos & $72111 / 72112$ & 0.385267 & 0.061412 & 0.072980 & 0.519659 \\
\hline
\end{tabular}

\section{A. Output Impacts}

As shown in Table 7, the total on-site impact of Performance Organizations contributed $\$ 52,498,624$ to the Mecklenburg County economy for fiscal year 2003-2004. Table 8 shows that the total on-site impact of Museums and Other Organizations resulted in additional output of $\$ 47,088,514$. The combined total on-site expenditure impact of both types of organizations was $\$ 99,587,138$. Of this total, $\$ 61,725,166$ was a direct impact; $\$ 19,701,842$ was an indirect impact; and \$18,160,130 was an induced impact.

The on-site impacts presented in Tables 7 and 8 reflect an adjustment process to account for the possibility that local attendees at performance events and museum activities would spend their money on other activities within the local economy if performances and museums were not available. The adjustment process involved three stages. First, total organizational revenue was allocated to 12 sources. Second, for each source, we determined the percentage of revenue originating from within Mecklenburg County and the percentage of revenue originating from outside the county. These percentages varied based on the source of the revenue stream and on attendance patterns.

Table 7

Output Impacts: Performance Organizations (2004 dollars)

\begin{tabular}{lcccc}
\hline Category & Direct Impact & Indirect Impact & Induced Impact & Total Impact \\
\hline On-Site Impacts & & & & \\
Performing arts companies & $34,393,332$ & $\$ 8,706,190$ & $\$ 9,399,101$ & $\$ 52,498,624$ \\
Off-Site Impacts & & & & \\
Food services and drinking places & $8,100,365$ & $\$ 2,348,037$ & $\$ 2,069,254$ & $\$ 12,517,656$ \\
Gasoline stations & 675,030 & $\$ 211,208$ & $\$ 179,090$ & $\$ 1,065,328$ \\
Miscellaneous store retailers & $1,356,984$ & $\$ 500,642$ & $\$ 339,218$ & $\$ 2,196,844$ \\
Hotels and motels, including casinos & $1,618,416$ & $\$ 321,676$ & $\$ 386,049$ & $\$ 2,326,141$ \\
\hline Total Off-Site & $11,750,796$ & $\$ 3,381,562$ & $\$ 2,973,611$ & $\$ 18,105,969$ \\
\hline Total & $46,144,128$ & $\$ 12,087,753$ & $\$ 12,372,712$ & $\$ 70,604,593$ \\
\hline
\end{tabular}


Table 8

Output Impacts: Museums and Other Organizations

(2004 dollars)

\begin{tabular}{lcccc}
\hline Category & Direct Impact & Indirect Impact & Induced Impact & Total Impact \\
\hline On-Site Impacts & & & & \\
Museums, historical sites, zoos & $\$ 27,331,834$ & $\$ 10,995,652$ & $\$ 8,761,028$ & $\$ 47,088,514$ \\
Off-Site Impacts & & & & \\
Food services and drinking places & $\$ 3,613,246$ & $\$ 1,047,364$ & $\$ 923,011$ & $\$ 5,583,621$ \\
Gasoline stations & $\$ 400,003$ & $\$ 125,155$ & $\$ 106,123$ & $\$ 631,281$ \\
Miscellaneous store retailers & $\$ 2,062,823$ & $\$ 761,052$ & $\$ 515,662$ & $\$ 3,339,537$ \\
Hotels and motels, including casinos & $\$ 1,338,679$ & $\$ 266,076$ & $\$ 319,322$ & $\$ 1,924,076$ \\
\hline Total Off-Site & $\$ 7,414,750$ & $\$ 2,199,647$ & $\$ 1,864,118$ & $\$ 11,478,515$ \\
\hline Total & $\$ 34,746,584$ & $\$ 13,195,299$ & $\$ 10,625,146$ & $\$ 58,567,029$ \\
\hline
\end{tabular}

Third, for each source, the in-county portion of the revenue was adjusted downward to reflect the concept of local resident re-spending and the off-setting effect of leakage blocking associated with the presence of local cultural organizations and events.

The third step in the adjustment process presented the greatest difficulty. For the 12 sources of revenue, the allocation of the in-county and out-of-county portions was based on actual records of attendance for ticket revenue, concessions, and merchandise sales. However, for other sources, additional assumptions had to be made. For advertising revenue, corporate/business donations, foundation donations, grant funding, interest income, and other sources, we assumed that 100 percent came from outside the county. For ASC funds, private donations, and in-kind donations, we assumed that 100 percent originated from within the county. These in-county sources were then discounted to reflect the re-spending/leakage blocking aspect; specifically, we used a re-spending/leakage blocking adjustment of 50 percent.

Based on the results from patron surveys, we decided not to make any local adjustment for ticket revenue, concessions, and merchandise sales. Survey responses indicated that if there were no local performance organizations, then local attendees would go outside the area to attend about one-quarter the number of events they attend within the county. The average ticket price of local performance events was $\$ 13.68$. In our view, local residents who attend events outside of the local region would spend close to the same amount for tickets and would incur additional travel costs that would likely be in excess of three times the average ticket price of $\$ 13.68$. As a result, if no local events were available, local attendees would likely spend about the same amount or more on attending events outside of the county as they currently spend for events within the county. Therefore, because local events represent possible leakage blocking, no adjustment was made for local ticket, concession, and merchandise spending. Survey results for museum patrons indicated that a similar approach should be applied to the ticket revenue, concessions, and merchandise sales of these organizations.

Tables 7 and 8 also provide the off-site impacts for Performance Organizations and Museums and Other Organizations. The off-site impacts were estimated for (1) Food services and drinking places, (2) Gasoline stations, (3) Miscellaneous store retailers, and (4) Hotels and motels, including casinos. Estimates of direct expenditures for each of these four categories of off-site establishments were based on a mail survey of performance and museum attendees. This survey was conducted in the fall of 2004, with 350 surveys sent to randomly selected patrons of both performance and museum affiliates. The response rate was approximately 30 percent.

The survey results indicated that both museum and performance patrons would attend events in other cities if museum and performance activities were not available within the Charlotte region. The museum survey estimates suggested that local resident expenditures on off-site activities would result in a leakage blocking level of 15.4 percent. The performance survey estimates suggested that local resident expenditures on off-site activities would result in a leakage blocking level of 27 percent. The off-site expenditures by local residents were adjusted downward to reflect these estimates. 
For Performance Organizations, Table 7 shows an off-site direct expenditure impact at Food services and drinking places of $\$ 8,100,365$ and a total impact (including indirect and induced expenditures) of $\$ 12,517,656$. Gasoline stations accounted for an off-site total impact of $\$ 1,065,328$. Miscellaneous store retailers accounted for another $\$ 2,196,844$, and Hotels and motels for an additional $\$ 2,326,141$. The off-site total expenditure impact for Performance Organizations in 2003-2004 was $\$ 18,105,969$.

For Museums and Other Organizations, Table 8 shows an off-site direct expenditure impact at Food services and drinking places of $\$ 3,613,246$ and a total impact of $\$ 5,583,621$. Gasoline stations accounted for an off-site total impact of $\$ 631,281$. Miscellaneous store retailers accounted for another $\$ 3,339,537$, and Hotels and motels for an additional $\$ 1,924,076$. The off-site total expenditure impact for Museums and Other Organizations in 2003-2004 was $\$ 11,478,515$.

The combined off-site direct impact of Performance Organizations and Museums and Other Organizations on the Mecklenburg economy was $\$ 19,165,546$. The combined off-site total expenditure impact of Performance Organizations and Museums and Other Organizations on the Mecklenburg economy was $\$ 29,584,484$ (the sum of the direct, indirect, and induced impacts).

Table 9 provides the total expenditure impacts by summing the on-site and off-site impacts presented in Tables 7 and 8. The combined expenditure impact of all the organizations in this study was $\$ 129,171,622$. This is the amount by which the Mecklenburg County economy benefited in 2003-2004 from the operation of the ASC and its affiliate organizations.

Table 9

Total Output Impacts

(2004 dollars)

\begin{tabular}{lcccc}
\hline Category & Direct Impact & Indirect Impact & Induced Impact & Total Impact \\
\hline $\begin{array}{l}\text { On-Site Impacts } \\
\text { Total On-Site }\end{array}$ & $\$ 61,725,166$ & $\$ 19,701,842$ & $\$ 18,160,130$ & $\$ 99,587,138$ \\
$\begin{array}{l}\text { Off-Site Impacts } \\
\text { Total Off-Site }\end{array}$ & $\$ 19,165,546$ & $\$ 5,581,209$ & $\$ 4,837,729$ & $\$ 29,584,484$ \\
\hline Total & $\$ 80,890,712$ & $\$ 25,283,051$ & $\$ 22,997,858$ & $\$ 129,171,622$ \\
\hline
\end{tabular}

\section{B. Employment Impacts}

Tables 10, 11, and 12 report the on-site, off-site, and total employment impacts measured in full-time equivalent jobs. Table 10 indicates that there were 597 direct on-site Performance Organization jobs; using the employment multipliers in Table 5, another 133 indirect (supplier chain) jobs and 93 induced jobs resulted from this on-site activity. Thus, the total on-site employment impact of the Performance Organizations on the Mecklenburg economy was 824 jobs. In a similar manner, Table 11 shows the total on-site employment impact of Museums and Other Organizations to be an additional 770 full-time equivalent jobs. 
Table 10

Employment Impacts: Performance Organizations: 2004 (in number of jobs created)

\begin{tabular}{lcccc}
\hline Category & Direct Impact & Indirect Impact & Induced Impact & Total Impact \\
\hline On-Site Impacts & & & & \\
Performing arts companies & 597 & 133 & 93 & 824 \\
Off-Site Impacts & & & & \\
Food services and drinking places & 203 & 19 & 21 & 244 \\
Gasoline stations & 12 & 2 & 2 & 15 \\
Miscellaneous store retailers & 34 & 5 & 3 & 35 \\
Hotels and motels, including casinos & 275 & 28 & 31 & 41 \\
\hline Total Off-Site & 872 & 162 & 124 & 1,158 \\
\hline Total & &
\end{tabular}

Table 11

Employment Impacts: Museums and Other Organizations: 2004 (in number of jobs created)

\begin{tabular}{lcccc}
\hline Category & Direct Impact & Indirect Impact & Induced Impact & Total Impact \\
\hline On-Site Impacts & & & & \\
Museums, historical sites, zoos & 273 & 305 & 192 & 770 \\
Off-Site Impacts & & & & \\
Food services and drinking places & 91 & 1 & 10 & 109 \\
Gasoline stations & 7 & 7 & 5 & 53 \\
Miscellaneous store retailers & 28 & 2 & 3 & 34 \\
Hotels and motels, including casinos & 28 & 19 & 19 & 204 \\
\hline Total Off-Site & 166 & 324 & 211 & 974 \\
\hline Total & 440 & &
\end{tabular}

Tables 10 and 11 also present the off-site employment impacts for (1) Food services and drinking places, (2) Gasoline stations, (3) Miscellaneous store retailers, and (4) Hotels and motels, including casinos. Direct off-site employment resulting from the Performance Organizations totaled 275 jobs in these four industry categories. Using the employment multipliers in Table 5 indicates that these 275 direct off-site jobs supported an additional 28 indirect and 31 induced jobs, for a total off-site employment impact of 334 jobs. Museums and Other Organizations provided an additional 166 direct, 19 indirect, and 19 induced off-site jobs.

Table 12 shows that the combined on-site and off-site employment impact of Performance Organizations and Museums and Other Organizations on the Mecklenburg economy was 2,132 full-time equivalent jobs in 20032004. This total included 1,312 direct jobs, 485 indirect (supplier chain) jobs, and 335 induced jobs.

Table 12

Total Employment Impacts: 2004 (in number of jobs created)

\begin{tabular}{lcccc}
\hline Category & Direct Impact & Indirect Impact & Induced Impact & Total Impact \\
\hline $\begin{array}{l}\text { On-Site Impacts } \\
\begin{array}{l}\text { Total On-Site } \\
\text { Off-Site Impacts }\end{array}\end{array}$ & 870 & 438 & 285 & 1,593 \\
Total Off-Site & 441 & 47 & 50 & 539 \\
\hline Total & 1,312 & 485 & 335 & 2,132 \\
\hline
\end{tabular}




\section{C. Earnings Impacts}

As shown in Table 13, the total on-site impact of Performance Organizations resulted in $\$ 19,247,540$ of earnings in Mecklenburg County for fiscal year 2003-2004. Table 14 indicates that the total on-site earnings impact of Museums and Other Organizations was \$21,431,137 for fiscal year 2003-2004. The combined total on-site earnings impact of both types of organizations, shown in Table 15 , was $\$ 40,678,678$. Of this total, $\$ 27,954,179$ was a direct impact; $\$ 7,168,380$ was an indirect impact; and $\$ 5,556,130$ was an induced impact.

Table 13

2004 Earnings Impacts: Performance Organizations (2004 Dollars)

\begin{tabular}{lcccc}
\hline Category & Direct Impact & Indirect Impact & Induced Impact & Total Impact \\
\hline On-Site Impacts & & & & \\
Performing arts companies & $\$ 13,616,664$ & $\$ 2,755,273$ & $\$ 2,875,615$ & $\$ 19,247,540$ \\
Off-Site Impacts & & & & \\
Food services and drinking places & $\$ 2,777,518$ & $\$ 661,257$ & $\$ 633,076$ & $\$ 4,071,843$ \\
Gasoline stations & $\$ 226,815$ & $\$ 72,468$ & $\$ 54,791$ & $\$ 354,074$ \\
Miscellaneous store retailers & $\$ 487,341$ & $\$ 171,775$ & $\$ 103,785$ & $\$ 762,901$ \\
Hotels and motels, including casinos & $\$ 623,522$ & $\$ 99,390$ & $\$ 118,112$ & $\$ 841,024$ \\
\hline Total Off-Site & $\$ 4,115,196$ & $\$ 1,004,890$ & $\$ 909,764$ & $\$ 6,029,842$ \\
\hline Total & $\$ 17,731,860$ & $\$ 3,760,163$ & $\$ 3,785,379$ & $\$ 25,277,382$ \\
\hline
\end{tabular}

Table 14

2004 Earnings Impacts: Museums and Other Organizations (2004 Dollars)

\begin{tabular}{lcccc}
\hline Category & Direct Impact & Indirect Impact & Induced Impact & Total Impact \\
\hline On-Site Impacts & & & & \\
Museums, historical sites, zoos & $\$ 14,337,515$ & $\$ 4,413,107$ & $\$ 2,680,515$ & $\$ 21,431,137$ \\
Off-Site Impacts & & & & \\
Food services and drinking places & $\$ 1,238,939$ & $\$ 294,960$ & $\$ 282,390$ & $\$ 1,816,285$ \\
Gasoline stations & $\$ 134,404$ & $\$ 42,942$ & $\$ 32,467$ & $\$ 209,813$ \\
Miscellaneous store retailers & $\$ 740,832$ & $\$ 261,124$ & $\$ 157,769$ & $\$ 1,159,725$ \\
Hotels and motels, including casinos & $\$ 515,749$ & $\$ 82,211$ & $\$ 97,697$ & $\$ 695,657$ \\
\hline Total Off-Site & $\$ 2,629,923$ & $\$ 681,238$ & $\$ 570,323$ & $\$ 3,881,480$ \\
\hline Total & $\$ 16,967,438$ & $\$ 5,094,345$ & $\$ 3,250,838$ & $\$ 25,312,617$ \\
\hline
\end{tabular}

Tables 13 and 14 also provide the off-site earnings impacts for Performance Organizations and Museums and Other Organizations. The off-site earnings impacts were estimated for (1) Food services and drinking places, (2) Gasoline stations, (3) Miscellaneous store retailers, and (4) Hotels and motels, including casinos. The levels of direct earnings for each of these four categories of off-site establishments were based on the output impacts estimated earlier and on the average level of earnings in these industries per dollar of output.

For Performance Organizations, Table 13 shows an off-site direct earnings impact at Food services and drinking places of $\$ 2,777,518$ and a total earnings impact (including indirect and induced earnings) of $\$ 4,071,843$. Gasoline stations accounted for an off-site total earnings impact of $\$ 354,074$. Miscellaneous store retailers accounted for another $\$ 762,901$, and Hotels and motels for an additional $\$ 841,024$. The off-site total earnings impact for Performance Organizations in 2003-2004 was \$6,029,842.

Table 14 shows that the off-site total earnings impact of Museums and Other Organizations was $\$ 3,881,480$. The combined total off-site earnings impact of Performance Organizations and Museums and Other Organizations on the Mecklenburg economy was \$9,911,321. 
Table 15 shows that the combined earnings impact of all the organizations in this study was $\$ 50,589,999$. This is the amount by which Mecklenburg County earnings were increased in 2003-2004 by the operation of the ASC and its affiliate organizations.

Table 15

Total Earnings Impacts

(2004 dollars)

\begin{tabular}{lcccc}
\hline Category & Direct Impact & Indirect Impact & Induced Impact & Total Impact \\
\hline $\begin{array}{l}\text { On-Site Impacts } \\
\begin{array}{l}\text { Total On-Site } \\
\text { Off-Site Impacts }\end{array}\end{array}$ & $\$ 27,954,179$ & $\$ 7,168,380$ & $\$ 5,556,130$ & $\$ 40,678,678$ \\
Total Off-Site & $\$ 6,745,119$ & $\$ 1,686,128$ & $\$ 1,480,086$ & $\$ 9,911,321$ \\
\hline Total & $\$ 34,699,298$ & $\$ 8,854,508$ & $\$ 7,036,216$ & $\$ 50,589,999$ \\
\hline
\end{tabular}

\section{SUMMARY AND CONCLUSIONS}

Table 16 presents a summary of the output, employment, and earnings impacts of the ASC and its affiliate organizations on the Mecklenburg County economy in the 2003-2004 fiscal year. The quality of life and the economy of Mecklenburg County are clearly and substantially enhanced through the events, activities, and services provided by the affiliated members of the ASC. The activities and operations of these organizations generated a total output impact of $\$ 129,171,622$ in 2003-2004. This level of economic activity supported 2,132 full-time equivalent jobs and generated $\$ 50,589,999$ in total earnings. In addition, the 5,974 volunteers, working an average of 5.39 hours per week, provided the equivalent of 805 full-time employee work-years for the organizations in this study. The value of the output of these volunteers is not measured here, but the quality and quantity of the services provided by these volunteers significantly increased the economic impact of Charlotte's cultural organizations.

Table 16

Summary of Output, Employment, and Earnings Impacts: 2004

\begin{tabular}{cccc}
\hline Category & Total On-Site Impact & Total Off-Site Impact & Total Overall Impact \\
\hline Output & $\$ 99,587,138$ & $\$ 29,584,484$ & $\$ 129,171,622$ \\
Employment & 1,593 & 539 & $\$ 2,132$ \\
Earnings & $\$ 40,678,678$ & $\$ 9,911,321$ & $\$ 50,589,999$ \\
\hline
\end{tabular}

\section{REFERENCES}

1. Alliance for the Arts. (1997). The Economic Impact of the Arts on New York City and New York State. Retrieved from http://allianceforarts.org/research/ec impact/97_study.pdf.

2. Buehler, Daniel, and Erin Trapp. (2001). The Economic Impact of Oregon's Nonprofit Arts Sector. Retrieved from http://www.oregonartscommission.org/pdf/westaf.pdf.

3. Chiappe, Jon, and Stephen Nelson. (2003). Economic Impact of the Arts in Oklahoma. Retrieved from http://www.swosu.edu/cebd/docs/oklahoma arts council.pdf.

4. Connaughton, John E., and Rob Roy McGregor. (2001). The Economic Impact of the Affiliated Members of The Charlotte Arts \& Science Council: 1999-2000. (Charlotte, NC: University of North Carolina at Charlotte).

5. DeMaio, Lucia. (2004). Creativity and the Economy: An Assessment of the Economic Impact of Missouri's Creative Industries. Retrieved from http://www.ded.mo.gov/researchandplanning/pdfs/creative industries.pdf.

6. Gazel, Ricardo C., and R. Keith Schwer. (1997). Beyond Rock and Roll: The Economic Impact of the Grateful Dead on a Local Economy. Journal of Cultural Economics, 21, 41-55. 
7. Minnesota IMPLAN Group. (2001). IMPLAN Professional: Social Accounting \& Impact Analysis Software, 2nd Edition. (Stillwater, MN: Minnesota IMPLAN Group, Inc.).

8. North Carolina Arts Council. (2004). Just the Ticket: The Arts Make Money in North Carolina. Retrieved from http://www.ncarts.org/pdf/Just_the_Ticket.pdf.

9. Real Estate Research Consultants. (2004). Looking at the Arts in Central Florida: A Summary of the Job and Related Impacts. Retrieved from http://www.florida-arts.org/resources/economicimpactofthearts.htm.

10. Robey, James E., and Jack Kleinhenz. (2000). Economic Impact of the Cleveland Museum of Art: A Tourism Perspective. Retrieved from http://www.clevelandart.org/downloads/impact.pdf.

11. Stronge, William. (2004). Economic Impact of Florida's Arts and Cultural Industry. Retrieved from http://www.florida-arts.org/resources/economicimpactofthearts.htm.

12. Swenson, Dave, and Liesl Eathington. (2003). The Creative Economy in Iowa. Retrieved from http://www.culturalaffairs.org/media/reports_and_studies/Creative.pdf.

13. Wessex Group, Ltd. (2000). Virginians for the Arts: The Economic Impact of Arts and Cultural Organizations in Virginia. Retrieved from http://www.arts.virginia.gov/resources/reports/wessex.pdf.

\section{$\underline{\text { NOTES }}$}


NOTES 